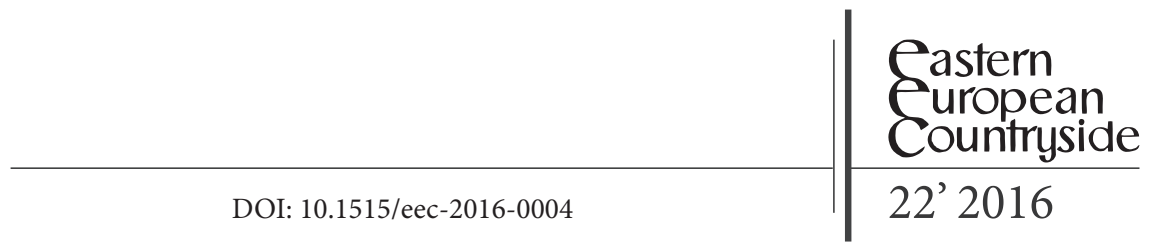

Eva Perger

Great Plain Research Department, Institute for Regional Studies Centre for Economic andRegional Studies, Hungarian Academy of Science, Hungary

\title{
Local Responses to the Structural Changes of National Development Policyin Hungarian Rural Regions
}

\begin{abstract}
The paper is based on the preliminary results of an ongoing research programme supported by the Hungarian Scientific Research Fund. The objective of the research is to find out how local actors react to the changing development policy context, how it shapes the local practices of local agents, and how such interactions influence local society and the development of rural micro-regions. The main pillars of the study are subject-oriented case-studies in two rural microregions. The pilot regions are very similar in terms of geographical location, natural resources, population, territory, settlement structure and economicsocial status, yet they have followed a very different development track, mainly due to the different local reactions to the changing state development policy. Our research demonstrates that the key factor of local success is multi-level (settlement, micro-region) cooperation between various (public, private and civil) local stakeholders. The crucial demand for a main facilitator of local cooperation could be satisfied by the local government, provided that it is able to adapt to the frequent changes leading to the emergence of new social networks. No evidence is found to indicate the existence of a 'project class' within the local rural societies assuming an intermediary role between decision makers and
\end{abstract}


beneficiaries. The traditional structures of power (based on party- and economic hierarchy) seem to survive. Although project-based implementation has become predominant in development policy, the main arena of the 'struggle' to obtain development resources is still the political one.

Keywords: rural differentiation; national development policy; local reactions; 'projectification'; local government; social capital; project class

\section{Background}

Territorial aspects of rural restructuring and rural differentiation have constituted the focus of scientific debates for decades. According to the results of a complex research programme carried out in 2012-2013, by the Hungarian Academy of Sciences and the Hungarian National Rural Network ${ }^{1}$, the general restructuring process characterising European rural areas can also be observed in Hungary. It seems, however, that this process is less intensive and that new phenomena accompanying the transformation - such as rural gentrification or farming following a 'post-productivist' philosophy - are much less present than in the more developed countries of Europe. Statistical analyses of the LAU 1 territorial level demonstrate growing disparities among rural regions, although the case studies and interviews reveal that the differentiation is not as strong as has been presumed based on statistical results (Kovács, Farkas and Perger 2015). The rural space, in general, is characterised by deepening economic and social problems. The majority of the problems faced by rural areas, e.g. population loss, labour market imbalance, lack of workplaces and income, inactivity and unemployment, exodus of people with a higher educational level, lack of financial capital, poor conditions of the road network etc., are not region-specific phenomena. The processes of decline could be reversed, especially in suburban zones and certain isolated settlements where local asset-based initiatives are able to procure considerable external funding. The differences within the LAU1 level districts - between settlement-groups or settlements - are also significant. Territorial differentiation, besides its

1 The main results of the complex rural research programme are published in the journal “Tér és Társadalom” (“Space and Society”), Vol. 29, No. 1 (2015) http://tet.rkk.hu/ index.php/TeT/issue/view/423. 
geographic determinants, is defined mainly by the heterogeneous social needs of certain localities, the adaptability of the communities, and local reactions to the challenges. The overall picture reveals a fragmented rural space predominantly characterised by a mosaic-type or a patchwork-type pattern in Hungary.

The concept of the differentiation can be interpreted in several ways; however, two main approaches seem to have gained predominance in the literature. Some argue that a new spatial configuration of the rural areas emerges as a consequence of the world-wide economic and social transformation and differentiation processes. Others hold that regional diversity - in addition to the general rural processes - is a result of local social structure and degree of identity. However, both the macro-scale and the micro-scale patterns of the rural differentiation in Europe are heavily influenced by public interventions. One of the most important policy fields is development policy (including sectoral, regional and rural development activities) which has undergone several changes since the political changeover and has increasingly been shaped by supranational (EU) norms and "expectations" in Hungary. The patchwork-type territorial structure suggests that the development of different micro-regions or settlements is strongly affected by the reactions of the local agents (local governments, local institutions and enterprises, civil organisations, individuals) to the changing environment.

\section{The main research questions and methods}

The paper is based on the preliminary results of an ongoing research programme ${ }^{2}$. The main target of the study is to establish how the redefinition of relations between the nation-state, the market, and "civil" society are handled by individuals, local institutions and enterprises, and how such interactions have produced social space in Hungary over the last two decades. Amongst other issues (land use, household consumption, public education, urban restructuring), local development in rural regions is one of the thematic fields of the research. The general question of this work

2 The research is supported by the Hungarian Scientific Research Fund - OTKA 109269 'Institutional and individual responses to state restructuring in different geographical context'. 
package is how the changing development policy context is responded to by local actors, how it shapes the local practices of local agents, and how such interactions influence the local society and the development of rural micro-regions. What are the main factors which determine the reactions of the local agents? Has the changing state (and EU) development policy transformed locally embedded networks and the interactions of local agents, as well as their relationships with other scales (i.e. to regional, national and EU institutions)? What are the spatial consequences of the rescaling power in controlling development resources?

The above-mentioned questions are examined mainly through the use of qualitative methods. The review of the relevant literature is followed by an analysis of different state-level documents on regional and rural development policy (mainly development plans, regulations, evaluation studies). The reprocessing of the outputs of the 'Rural Research Program 2012-2013' enables us to obtain an up-to-date insight into the development practice of different rural micro-regions. The main pillars of the investigation are subject-oriented case-studies in two rural pilot regions. A total of 30 interviews are conducted in each region, supported by information assembled from statistical and document analyses related to the study areas.

\section{Literature review}

The institutional practices of the nation-state are mostly being shaped by supranational (EU) decisions demanding a rapid adaptation of local agents to subsequent changes. The impact of such processes has been interpreted and discussed in terms of institutional reforms (Perger 2010a, 2010b; Mezei 2013; Augustyn and Nemes 2014) and the spatial distribution of funds (NFH 2006; Lukovics and Lóránd 2010; Pannon, Hétfa and Budapest Int. 2013; Fertő and Varga 2014).

In terms of our research focus, the most significant studies concentrate on the local level and use empirical methods of field work. These studies point out that the internal contradictions of aid schemes and the impacts of the varying quantities of available internal resources induce a very complex process which further augments the diversity of rural areas (Fekete 2010; Kovács and Kabakchieva 2012; Perger, Kovács and Lennert 2014) and also confirms that subventions promote territorial cohesion to a much 
smaller extent than expected - in certain cases even producing a reverse impact (Kovács 2013; Nagy, Timár, Nagy and Velkey 2015). Some researchers argue that the primary criterion of success in the field of local development is the presence of a charismatic leader, preferably a mayor who is embedded in politics at the national level (Bódi, Fekete and Bódi 2010).

There are many theoretical studies, and those dealing with the effects of 'projectification' should be highlighted (Kovách and Kucerova 2006, 2010). They assume that project logic, as a new form of the redistribution of financial resources, should have remarkable effects on rural society by generating new social groups and new social networks. The quasi market of development resources instead of a top-down bureaucratic coordination would require the involvement of multiple actors. A 'partnership' between various actors would be crucial as well as local 'governance' instead of local 'government'. Since the new 'project class' has an intermediary role between decision makers and beneficiaries, their substantial knowledge and social capital would allow them to influence the allocation of funds. As a result, the traditional structures of power - based on party-and economic hierarchies - should become more complex. A study by Füzér (2013) lays out different models of how social capital is being redistributed in the context of urban and rural development. The study highlights that, in reality, the ' $E U$ ideal' model of smooth cooperation among the three chief actors - the political elites, the project classes and partnerships - is not always followed. According to the model of 'Beneficiarism' - due to the lack of bridging social capital among locals - the 'project class' itself 'produces' methods for the involvement of local actors. In the 'Clientalism' model, development projects deteriorate into the provision of selective favours for local clients. In the 'Annexation' model, local political and economic elites avoid sharing power with new actors and occupy the positions of project class themselves. The author argues that developments under both 'clientalism' and 'annexation' serve as reminders of the dark side of social capital. In the author's opinion, the chief criterion that differentiates urban and rural development regimes in the context of contemporary Hungarian society is the fact that rural societies frequently lack indigenous, local project classes due to their decapitated local social structures.

Although rural studies in Hungary contain an increasing number of references to the theory of 'social capital' and 'social networks', there are very few analyses clearly based on this concept. The verification of the 
'project class theory' is also still lacking. Amongst the existing studies, of particular relevance is a $\mathrm{PhD}$ paper which attempts to analyse the linkages between social capital and local development (Megyesi 2014). Based on two case studies, Megyesi argues that the existence of bonding social capital (family and neighbourhood relations) and bridging social capital (horizontal relations) clearly contributes to successfully accessing EU funding, while the existence of linking capital (vertical relations) is not necessary.

\section{Development policy institutions in Hungary and the local development practice in rural regions}

The transformation of development policy in Hungary has been a controversial process characterised mostly by frequent changes to the development tools, national regulation and institutions, as well as by a predominantly formal compliance with EU norms. After a transformation period when the old coordinative institutions - based on a system of central planning and redistribution - were removed and new indirect tools and new institutions emerged, the period spanning the mid-90s to 2004 could be characterised as a preparation phase for EU accession. This period was full of 'expectations' concerning decentralisation and the involvement of regional-local actors. New regional policy institutions with a coordinative role emerged (development councils and agencies at different territorial levels), yet the development funds still operated mostly on the basis of a departmental logic. During the period spanning 2004-2006, the national practice of regional development became slightly decentralised, although the newly established system for the management of the EU funds followed a centralised bureaucratic model and special proceedings. The allocation of EU funds was mostly based on departmental logic. The urge to construct regional institutions and local partnerships diminished. In 2007, the EU Funds' management tasks - with the exception of rural development - were detached from the traditional administration and transferred to the newly established National Development Agency (NDA). A new construction for the selection (priority projects) ensured that $35-45 \%$ of the frame of the Community Support Framework was allocated through direct governmental decisions at a project level. Regional development institutions took on a slightly more important role in the implementation, yet they operated under strict 
governmental control. As a result of the unambiguous centralisation process, political mechanisms became the main forms of coordination. Partnerships between various actors were often generated through a top-down process which was politically motivated and formal. Post-2010, the new government temporarily used the existing institutions and proceedings, but made significant changes with regards the staff of the NDA. Practically speaking, the EU Funds (with national co-finance) have remained the only source of funding, and thus the parallel structure of the national development system has all but disappeared. Due to the overall centralisation process, the local governments were deprived of several tasks and resources, and received less autonomy. In 2014, the operation of the NDA was terminated and all the institutions of the development policy were re-transferred to three major ministries. At this time, the Ministry of Agriculture also became a 'victim' of the concentration process since the Minister of the Prime Minister's Office became responsible for rural development. In the new planning period (20142020), the single Territorial and Settlement Development OP has become the main source of local development activities, which include centrally indicated resources for counties and county-level cities.

Several rural communities have received financial support in the last 25 years - mainly from EU funds. The development funds mostly remedied the infrastructural deficiencies, and improved the built environment of settlements, although a real development track was not actually designed. The generally poor performance is partly the result of the frequent changes in development policy institutions and the unambiguous centralisation process. Project-based implementation combined with a centralised and bureaucratic model often reduced the local creativity and innovation. The case studies of the 'Rural Research Program 2012-2013' indicated that, more often than not, an ad hoc development policy existed at the local level. Local development activities 'relying on internal resources' produced merely meagre results. The competition for winning the tenders weakened the local actors' propensity towards cooperation both in the public and the private sector. The dissension of the town and its surroundings was further reinforced by the duality of 'regional development' and 'rural development'. 


\section{Case studies}

\section{Characteristics of the selected micro-regions and their performance in attracting development funds}

The selected micro-regions of Mórahalom and Kunszentmiklós are typical rural areas situated on the Hungarian Alföld ('Great Plain') in a peripheral position. Mórahalom is located on the Serbian border, $21 \mathrm{~km}$ from the city of Szeged. The Kunszentmiklós region is an inner periphery on the northern border of Bács-Kiskun County near the Danube. Both regions are characterised by agricultural land use. The population $(26,000$ and 31,000$)$ and the territory $\left(535 \mathrm{~km}^{2}\right.$ and $\left.803 \mathrm{~km}^{2}\right)$ of the two micro-regions are very similar. There are 9 settlements in the Mórahalom and 10 settlements in the Kunszentmiklós region, neither of which - not even the central towns have more than 8,800 inhabitants. The economic indicators in both regions are typically far below the national average, although the social indicators are relatively good. On the basis of national development categories, both regions are considered preferred beneficiaries from the spatial development viewpoint. In the Kunszentmiklós region, the 'Soroksár' branch of the river Danube, and areas of natural reserve in the Mórahalom region, thermal water is often considered to have special natural values.

Despite all the similarities, the two micro-regions differ in terms of access and use of public funding. The performance in attracting national development funds between 1996 and 2008 was 'average' in Kunszentmiklós and 'outstanding' in the Mórahalom region according to a countrywide classification (NFGM 2009). Financial indicators of EU funds' absorption between 2004 and 2013 were also 'outstanding' in Mórahalom and 'average' in Kunszentmiklós (Pannon, Revita, Hétfa and Budapest Int. 2013). The 'average' status of the Kunszentmiklós region is merely due to outstanding performance in the field of rural development.

Thanks to its project activity and an efficient utilisation of the allocated funds, Mórahalom received more than twice the amount of financial assistance from the structural and cohesion funds than Kunszentmiklós during the period spanning 2004-2013 (Figure 1.). The allocated amount of funding between 2007 and 2010 was especially high in the Kunszentmiklós region due to a 22.5 billion priority project of the State Water Directorate 
based on a governmental decision. Nevertheless, the implementation of this project faced difficulties and the increased level of the allocated figure was not evident in the distributed amount.

The two regions shared a number of common characteristics. The rate of beneficiaries from the public sector was overwhelming in both regions. In addition, the percentage of the allocated funds in the framework of the Environmental and Energy OP was relatively high, although it was relatively low in the framework of the Economic Development OP and the Social Renewal OP - in comparison with the national average.

Mórahalom excelled in its relatively high percentage of allocated funds received in the framework of the Regional OP (36.3\%) and the relatively high weight of the civil sector beneficiaries (10\%). The Kunszentmiklós region constituted a special case among the Hungarian regions, as the amount of aid received from the Structural Funds was below that of the grant obtained from the European Agricultural Fund for Rural Development.

\section{The development trends of the pilot regions}

Although impact assessments on EU cohesion policy have not pointed out an unambiguous and close connection between the received funds and regional development at any territorial level, our two pilot regions are excellent examples of the possibility of the existence of such coherency. Of particular note here is a study by Fertö-Varga (2013), which classifies the Hungarian micro-regions based on a multi-dimensional index measuring the overall level of regional development and quality of life. It demonstrates that the position of Mórahalom did not change between 2002 and 2008, while that of Kunszentmiklós deteriorated. In an analysis examining the dynamics of Hungarian micro-regions based on a complex social-economic index during the period 2000-2010 (Pannon-Revita-Hétfa-Budapest Int. 2013), Mórahalom is listed among those regions demonstrating the best development dynamics, while Kunszentmiklós is characterised by 'average' dynamics, which meant no change in its position.

Mórahalom is a dynamically developing town. Its population - due to immigration - has shown a slight increase. Since the mid-90s, more than 50 firms have settled down in the industrial park, employing more than 400 people. Thanks to the development of the public bath and related services, the town has over 450,000 visitors annually. The public infrastructure and 
the city centre have been totally reconstructed and several new public buildings have been built. The standard of public services is much higher than in other similar scale towns, and these facilities are available for all inhabitants of the micro-region.

The Kunszentmiklós micro-region shows signs of a stagnating area. The population loss is high, due both to the natural decrease and emigration. The region could not really recover from the post-transition crises and the collapse of large scale farming and the rural industry. The most serious problem remains the small number of workplaces. The industrial parks of the towns do not attract large enterprises. The natural-environmental and cultural heritage of the region has only a limited impact on the development. Some crucial development activities (construction of the sewage system and towncentre rehabilitation in Kunszentmiklós, health-care centre in Dunavecse) have just started in recent years.

\section{Local reactions to the changing development policy environment}

Local actors in the Mórahalom micro-region were very quick to recognise the challenges of the changing development policy determined by EU norms and regulations, i.e. during the pre-accession period. Thanks to the young, well-prepared and competent mayor who was also embedded in the national politics, the Mórahalom local government played a key organising and stimulating role in this process and was very active in all fields (local economy, civil sector, public services etc.). Strategic planning involving the main local actors was also initiated by the leadership of the 'town,' both at the settlement and the micro-regional level. Planning documents have formed the basis for all local development activities. With the help of the municipality, all local actors were following the calls for proposals (both national and EU funds) and were searching for good opportunities that matched their strategies. The local government office and the local public institutions (public bath, family health-care centre, library, schools) were also encouraged to pursue intense project activities. In this way, each local actor could acquire the ability to adapt flexibly and quickly to the changes of state institutions and regulation. Good partnership relations and cooperation were established among different (public - private - civil) local actors and among the settlements of the region. The local government of Mórahalom did not merely adjust to the new projectlogic of the distribution of funds, but proved to be very innovative by creating 
a special development model. It established non-profit local 'project-firms' for special development activities (e.g. municipal constructions, television line and press, special health-care centre, social care service for disabled children, touristic destinations, etc.). These companies had also become high-level public service suppliers (e.g. public utility service, special health-care service, crèches and nurseries, public cultural events) mostly financed by new project sources or through their own income. Several qualified newcomers could find a job in the public or non-profit (de facto quasi-public) sector. Those who had special knowledge of project proposals and management were mostly also the employees of these sectors. They were the representatives of the applicants and did not have an intermediary role between the decision makers and beneficiaries. Since they depended on the local political power, they could not be considered 'members of the project class' as classified by Kovach, and had no special power based on knowledge or social capital. Paradoxically speaking, the mayor of the town and his staff were the most competent in the 'project' field and were personally the most important actors in the local and the higher scale social networks. The local economy was also constructed through the active participation of the local government. This did not imply merely using indirect tools such as the creation of the first 'industrial park' of the Southern Great Plain, but also the role of the founder and the owners of local companies. The first qualified producing and selling union in Hungary was also organised here with a contribution from the municipality. The local government is still the owner of several non-profit companies, but also has a small share in 'business like' firms such as the one operating the new fourstar thermal hotel.

Local actors in the Kunszentmiklós region became aware of the challenges of the new development policy regime very late. The development activity in this micro-region traditionally relied on the large state organisations such as the military (garrison in Szabadszálás), the National Park, the state water directorate (Dunavecse), big state firms (Kunszentmiklós) and big cooperative farms (in almost all settlements). The good political acquaintances of local leaders were the key elements when it came to accessing local development resources. This attitude, namely reliance on the "linking" of politicians' social capital (anticipating that special persons coming from the region, such as members of Parliament, state secretaries, and mayors embedded in national level politics are able to 'bring' additional resources) has changed very slowly. The region was characterised by the lack of long-run strategic 
planning both at the settlement and the micro-regional level, as well as by weak cooperation between the different local actors or settlements. The town of Kunszentmiklós is the centre of administration and the supplier of several middle-level public services, although it could not fulfil its spatial organisation role in development policy. The development of the region has also been set back by the steady competition among the three similar sized towns (Kunszentmiklós, Dunavecse, Szabadszállás). These towns - traditionally relying on the public sector and state interventions - have not been able to play the necessary organising and stimulating role, nor have they managed to adapt to the new project-based development regime. Their project activity has mostly been based on ad-hoc decisions following the prompt call for proposals. The preparation of project proposals and project management tasks was usually contracted out to consulting companies coming from cities outside the region (Budapest, Kecskemét, Dunaújváros) and sometimes to those firms which had drawn the attention of local governments to the actual call for proposal. The only group of local actors which was able to adapt surprisingly soon and efficiently to the changing development institutions and regulations was that containing the agrarian sector and rural development - mostly farmers, specialists in the agro-food industry and civil servants in local state offices or local offices of the Chamber of Agriculture. The farmers are well organised and cooperate at the settlement-group, micro-region and county level. This is presumably due to the fact that despite the persecution of farmers - the tradition of private farming had been preserved in this region even under the socialist regime. Family farm owners were able to quickly learn how to apply for development funds with the help of the local counselling services or their educated family members. In several cases, owners of large farms were able to find a consulting company which prepared their project proposals relying on their economic network (engrossers, contractors or other farmers), although these companies never belonged to the micro-region.

\section{Conclusions}

Both the empirical research in the framework of the Rural Research Project 2012-2013 and the 'subject-orientated' field work revealed that the local responses to structural changes of the state development policy could exert 
a considerable impact on local development, and thus on the territorial differentiation of the rural regions. The two case studies from recent research demonstrate this context very well. The pilot regions are very similar in terms of their geographical location, natural resources, population, territory, settlement structure, and economic and social status, although they have followed diverse development tracks due to different local reactions. The development of the two central towns reveals the most striking disparities. Conversely, in Kunszentmiklós - a town with remarkable urban traditions time seems to have stopped; Mórahalom - a settlement which gained town ranking only in 1989 - has become one of the most dynamic settlements of the South Great Plain. Our research demonstrates that cooperation between various local actors is the key factor when it comes to local success. One assumption that seems accurate is that the existence of bridging social capital clearly assists with successes in accessing EU funding, although the existence of linking capital does not necessarily seem to be true. It must be pointed out that the public sector - mainly the local government - tends to be the main facilitator of local cooperation in all fields. In backward rural regions, the local government is also the main actor in the local economy. Private direct investments also depend, to a great extent, on public assistance. Charismatic leaders who achieve progress not only in attracting enterprises or development funds but also in building local communities, promoting and operating external co-operation were able to play a key role in local development. The 'Mórahalom case' proves that the 'annexation' model does not necessarily destroy the local bridging capital; moreover - in the absence of a 'local project class' - this is the only chance to create new social networks.

No evidence could be found for the existence of a 'project class' in the local rural societies that has an intermediary role between decision makers and beneficiaries. The traditional structures of power (based on partyand economic hierarchies) seem to survive. Although the project-based implementation has become predominant in development policy, the main arena of the 'struggle' to obtain development resources is still the political one. 


\section{References}

Augustyn, A., Nemes, G., 2014. Catching up with the West? Europeanisation of rural policies in Hungary and Poland. Studies in Agricultural Economics, 116(3), pp. 114-121. Available at: http://dx.doi.org/10.7896/j.1419.

Bódi, F., Fekete, A. \& Bódi, M., 2011. Fejlesztési források abszorpciója az apró-, kisés középvárosok erőterében [Absorption of Development Funds in Functional Regions of Small and Medium Size Towns]. In: F. Bódi and F. Gergely (eds.), Helyi szociális ellátórendszer Magyarországon. Debrecen: Egyetemi Kiadó, pp. 281-297. Available at: http://dx.doi.org/10.5484/bodi_fabian_helyi_szocialis_ ellatorendszer,http://hdl.handle.net/2437/222678.

Fekete, A., 2010. Alulnézetből. Vélemények a lokális fejlesztésről [From Bottom-Up Perspective. Views on Local Development]. A Falu, 25(3), pp. 35-46.

Fertő, I. \& Varga, Á., 2015. Az európai uniós támogatások hatása a kistérségek helyzetére [Impact of the EU Supports on the State of the Sub-Regions]. Tér és Társadalom, 29(1), pp. 116-31. Available at: http://dx.doi.org/10.17649/ tet.29.1.2667.

Füzér, K., 2013. The project class: making and breaking social capital in urban and rural development. Szociális Szemle, 6(1-2), pp. 28-34. Available at: http:// szociologia.btk.pte.hu/sites/default/files/attached_files/szsz2013_28-34.pdf.

Kovách, I., Kucerova, E., 2006. The Project Class in Central Europe: The Czech and Hungarian Cases. Sociologia Ruralis, 46(1), pp. 3-21. Available at: http://dx.doi. org/10.1111/j.1467-9523.2006.00403.x.

Kovách, I., Kučerova, E., 2009. The Social Context of Project Proliferation-The Rise of a Project Class. Journal of Environmental Policy and Planning, 11(3), pp. 203221. Available at: http://dx.doi.org/10.1080/15239080903033804.

Kovács, A.D., Farkas, J.Z. \& Perger, É., 2015. A vidék fogalma, lehatárolása és új tipológiai kísérlete [Definition, Delimitation and Classification of rural areas]. Tér és Társadalom, 29(1), pp. 11-34 Available at: http://dx.doi.org/10.17649/ tet.29.1.2674.

Kovács, K., 2013. Területi, társadalmi hátrányok és beavatkozási politikák [Territorial and Social Drawbacks and Public Interventions]. In: K. Kovács \& M. M. Váradi, (eds.) Hátrányban, vidéken, Budapest: Argumentum Kiadó, pp. 25-56. Available at: http://hdl.handle.net/11155/293.

Kovács, K., Kabakchieva, P., 2012. Transmitting Western Norms: The SAPARD Program in Eastern Europe. In: V. Zentai, M.J. Kovács (eds.) Capitalism from Outside?: Economic Cultures in Eastern Europe after 1989, Budapest: Central European University Press, pp. 127-148. Available at: http://www.ceupress.com/ books/html/CapitalismfromOutside.htm.

Lukovics, M. \& Lóránd, B., 2010. A versenyképesség és a pályázati forrásallokáció kistérségi szinten [Competitiveness and Tendering Efficiency on the Level 
of Micro-regions]. Tér és Társadalom, 24(2), pp. 81-102. Available at: http://tet. rkk.hu/index.php/TeT/article/view/1792/3553.

Megyesi, G., 2014. Fejlesztéspolitika helyben - Doktori értekezés [Development policy on local level - Ph.D Thesis]. ELTE p. 230, Available at: http://tatk.elte.hu/ file/MegyesiGergelyBoldizs_r_PhDdolg.pdf.

Nagy, E., Timár, J., Nagy, G. \& Velkey, G., 2015. A társadalmi-térbeli marginalizáció folyamatai a leszakadó vidéki térségekben [The processes of socio-spatial marginalization in declining rural spaces]. Tér és Társadalom, 29(1), pp. 35-52 Available at: http://dx.doi.org/10.17649/tet.29.1.2680.

NFGM, 2009. A hazai területfejlesztési támogatási rendszer átfogó értékelése [Crosscutting evaluation of the national regional development system]. NFGM p. 236, Available at: www.vati.hu/index.php?article $=21380 \&$ langcode $=$ hu\&menu=19497.

Pannon Elemző Iroda, Revita Alapítvány, Hétfa Elemző Központ, Budapest Intézet, 2013. A fejlesztési források szerepe a leszakadó térségek dinamizálásában [The role of development funds in backward regions]. p. 140, Available at: $h t t p s: / / w w w$. palyazat.gov.hu/download.php?objectId $=48345$.

Perger, É., Kovács, A. \& Lennert, J., 2014. Fejlesztési tapasztalatok vidéki térségekben. [Development experiences in rural areas]. A falu, 29(2), pp. 39-50. Available at: http://hdl.handle.net/11155/658.

Perger, É., 2010. Az EU kohéziós politika kormányzati irányításának magyar sajátosságai. (Characteristics of the Management System for EU Cohesion Policy in Hungary). Tér és Társadalom, 24(1), pp. 119-136. Available at: http://tet.rkk.hu/ index.php/TeT/article/view/1299/2594.

Perger, É., 2010. Az EU regionális támogatások hatása a területi decentralizáció folyamataira [Impact of EU Regional Policy on Decentralization Process]. Comitatus, Önkormányzati szemle, 20(1-2), pp. 3-20. 